\section{Evaluation ofBite Force and Masticatory Performance: Complete Denture vs Mandibular Overdenture Users}

Anna Paula da Rosa Possebon ${ }^{1} \mathbb{D}$, Alessandra Julie Schuster ${ }^{1} \mathbb{B}$, Amália

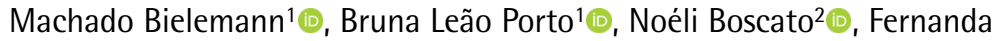
Faot $^{2}$ (1)
'School of Dentistry, UFPel - Universidade Federal de Pelotas, Pelotas, RS, Brazil ${ }^{2}$ Department of Restorative Dentistry, School of Dentistry, UFPel - Universidade Federal de Pelotas, Pelotas, RS, Brazil

Correspondence: Profa. Fernanda Faot, PhD, Rua Gonçalves Chaves 457, 96015-560 Pelotas, RS, Brasil. Tel: +55- 53-3225-6741. e-mail: fernanda.faot@gmail.com

\begin{abstract}
This cross-sectional observational study with 24 patients evaluated differences in bite force (BF) and masticatory performance (MP) between conventional complete denture (CCD) and implant mandibular overdenture (IMO) users and the correlation between these variables. The BF test was performed bilaterally with an occlusal force device. During the MP test, patients were asked to chew Optocal particles for 40 cycles. The Shapiro Wilk test was employed to verify the normality of the data, the student t test to identify differences between groups, and Pearson's correlation to investigate interrelationships between variables. A multiple linear regression was subsequently performed via the stepwise method. P values $\leq 0.05$ were considered statistically significant. Unlike IMO users, CCD users presented a significant difference $(25.6 \%)$ in BF between the dominant and non-dominant chewing side $(\mathrm{p}=0.04)$. IMO users presented significantly higher BF $(p=0.01)$ without presenting a dominant side $(p=0.38)$, and also performed significantly better for the following MP parameters: MPX50 values decreased by $27.25 \%$ in IMO users $(p=0.01)$, MPB decreased by $48.38 \%(p=0.01)$, and ME 5.6 decreased by $53.25 \%$ $(p=0.02)$, while ME2.8 increased by $151.57 \%(p=0.01)$. The BF and MPX50 in the IMO wearers group were negatively correlated $(-0.57 ; p=0.05)$; this correlation coefficient was the only parameter included in the multivariate regression model. IMO users have higher BF and better masticatory performance than CCD users, especially in terms of chewed particles size reduction. MP is correlated with a higher BF in IMO users through better particle trituration.
\end{abstract}

Key Words: bite force, masticatory performance, conventional complete dentures, implant mandibular overdentures.

\section{Introduction}

The masticatory function of patients rehabilitated with conventional complete dentures (CCD) is impaired when compared to alternatives such as implant-retained prostheses $(1,2)$. The McGill $(3)$ and the York Consensus (4) recommended that implant mandibular overdentures (IMO) supported by two implants are the minimum treatment offered to edentulous patients. IMO have increased retention and stability, which translate into an improvement in masticatory performance (MP). In addition, a large part of this improvement can be attributed to the increase in bite force $(\mathrm{BF})$ after rehabilitation with $\operatorname{IMO}(5,6)$.

The $B F$ is a biological variable that is potentially associated with MP, and has become a widely used proxy for analyzing the masticatory functionality resulting from different oral rehabilitations (5,7-9). Some studies (10-13) reported that the $B F$ of patients using IMO is much higher than the BF of CCD users; the BF doubles soon after implant installation (14), and can be up to 123\% higher after 1 year of implant placement, reflecting improved food trituration by the posterior teeth of the prosthesis (9). Thus, edentulous patients benefit from improved muscle activity after stabilization of the lower denture by two implants (15).
In addition, the $\mathrm{BF}$ is also affected by aging, since aging is associated with both loss in quantity and size of the muscle fibers in the masticatory muscles. In situations with a long period of edentulism, this condition is aggravated by the decrease in muscle density, which leads to muscular atrophy $(16,17)$. Thus, the weakening of the muscles involved in mandibular closure contributes to the decreased maximum bite force observed among CCD users (18).

The instability of the CCD is also thought to inhibit the full potential of the jaw muscles during chewing, since muscle strength increases immediately after stabilization of the implant prostheses by IMO (18). Furthermore, IMO users have thicker masseter muscles than completely edentulous CCD users (16). The beneficial impact on the neuromuscular system after transition to IMO is thought to occur within a rapid adaptation period with duration between 2 and 12 months, as additional changes are not observed after 1 year, even over long follow-up periods $(13,19)$.

Although BF is intrinsically linked to MP, so far there are no studies that evaluated how these parameters are correlated in totally edentulous patients rehabilitated with CCD and IMO. Thus, the present study aims to evaluate differences in BF and MP between CCD and IMO users 
and the correlation between these variables, using BF tests and objective masticatory function parameters. The null hypothesis to be tested is that there will be no difference between the CCD and IMO groups and no correlation between BF and MP.

\section{Material and Methods}

\section{Study Design}

This observational study with a cross-sectional design was approved by the Research Ethics Committee of the UFPEL School of Dentistry (protocol - 2.197.630/2017), and was carried out in accordance with the Declaration of Helsinki and described following the Guidelines for reporting Observational Studies (STROBE). The following inclusion criteria were applied for the CCD group: individuals should be totally edentulous and rehabilitated with new CCD made with thermo-polymerizable acrylic resin (VIPICRIL plus VIPI ${ }^{\circledR}$ - Pirassununga, SP, Brazil) and artificial acrylic resin teeth (Trilux - VIPI ${ }^{\circledR}$ - Pirassununga, SP, Brazil) mounted in bilaterally balanced occlusion. For inclusion in the IMO group, individuals should have mandibular overdentures retained by two reduced-diameter Facility implants (grade V Ti, NeoPoros surface - Neodent ${ }^{\circledR}$ - Curitiba, PR, Brazil) between the mental foramen, loaded with conventional loading (3 months after osseointegration). Individuals who were using their CCD or IMO for at least 3 months $\dot{+}$ wer were invited to participate in the study. The sample size calculation was based on the MP $(\times 50)$ outcome in the study by Van Kampen et al. (20), using the following mean \pm standard deviation data: CCD group $(4.5 \pm 0.8)$ and IMO group (3.6 \pm 0.6$)$. Taking into account $80 \%$ power $(a=20 \%)$, $95 \% \mathrm{Cl}, 10$ patients in each group were required, totaling 20 patients. To take dropouts into account, this was increased by $20 \%$. Thus, 24 individuals ( 12 CCD users and 12 IMO users) were invited to participate in the study, and everyone who agreed to participate signed an informed consent form. Sociodemographic sample characteristics such as gender, age, time since maxillary and mandibular edentulism, and mandibular degree of bone atrophy were all collected by the same evaluator (APP).

\section{Bite Force}

The bite force was analyzed using an Occlusal ForceKratos gnatodynamometer (model IDDKv4) using three 30-second measurements on each side of the patient's arch (21). The sensor was positioned between the 2 nd premolar and the 1st molar and the measurement was performed by a trained evaluator (BLP). The final reported value was calculated as the average of the 3 measurements. The sides with the highest and lowest BF values are hereafter referred to as the dominant side and non-dominant side, respectively (22).

\section{Masticatory Performance}

The masticatory function was assessed through the Masticatory Performance Test (MP) in which individuals chew a standardized portion (3.7g) of test food (Optocal) for 40 cycles counted and timed by a single evaluator (AMB). The masticated material was expelled in a paper filter and dried at room temperature for 7 days and subsequently processed by a stack of 9 sieves with decreasing mesh sizes ranging from $5.6 \mathrm{~mm}$ to $0.5 \mathrm{~mm}$ coupled on a shaker. The material retained in each sieve was weighed, and the MPX50 and MPB outcomes were calculated using the RosinRammler formula. The MPX50 value obtained reflects the average particle size and corresponds to the theoretical sieve opening through which 50\% of the crushed particles would pass. The MPB index reflects homogenization of the triturated particles, with lower MPB values corresponding to more homogeneous particle size distributions (5). The percentage of test food retention in the 5.6, 4.0, and 2.8 $\mathrm{mm}$ sieves is known as the masticatory efficiency (ME 5.6, ME 4.0, and ME 2.8, respectively).

\section{Statistical Analysis}

The data normality was tested by the Shapiro Wilk test. The Student t-test was used to check for differences between the groups, Pearson's correlation coefficient was used to test for associations between the MP with BF and sample characteristics. A subsequent multiple linear regression was performed via the stepwise method. $\mathrm{P}$ values $\leq 0.05$ were considered statistically significant for all analyses.

\section{Results}

The CCD group consisted of 8 women (66.67\%) and 4 men $(33.33 \%)$ with an average age of $62.33 \pm 7.35$ years and an average time since maxillary and mandibular edentulism of $24.00 \pm 15.03$ and $19.65 \pm 15.69$ years, respectively. The IMO group consisted of 9 women (75\%) and 3 men (25\%) with an average age $70.16 \pm 7.73$ years and an average time since maxillary and mandibular edentulism of 24.89 \pm 15.36 and $19.65 \pm 15.68$ years, respectively. The CCD group contained 7 (58.33\%) clinically atrophic individuals whereas the IMO group contained 9 (75\%). The majority $(n=16)$ of the participants are retired $(66.66 \%), 13$ are married (54.16\%), and 15 lost their teeth due to periodontal disease $(62.5 \%)$.

Table 1 lists the intergroup BF data and shows that the average $B F$ of IMO users was $127.52 \%$ higher than the average BF of CCD users $(p=0.01)$. All evaluated MP parameters were significantly different between the groups, except for the percentage of material retained in the 4.0 
$\mathrm{mm}$ sieve (ME 4.0). Compared to CCD users, IMO users had 27.25\% lower MPX50 values ( $p=0.01$ ), 48.38\% lower B-values ( $p=0.01)$, and $53.25 \%$ lower ME $5.6(p=0.02)$, while ME 2.8 was $151.67 \%$ higher $(p=0.01)$.

Table 2 lists the intragroup differences in BF between the dominant and non-dominant side of the groups. CCD wearers showed significant BF differences between the sides $(p=0.04)$ and the $B F$ of the non-dominant side was on average $25.6 \%$ lower. IMO users exerted statistically indistinguishable $\mathrm{BF}$ on each side $(\mathrm{p}=0.38)$.

No correlations were found between MP and $\mathrm{BF}$, gender, age, time since maxillary and mandibular edentulism, and degree of mandibular bone atrophy. There was only a significant negative correlation between MPX50 and BF (Table 3 ) in the IMO group (coef $=-0.57 ; p=0.05)$, indicating

Table 1. Intergroup differences: means (standard deviation; SD) (t-test;p $\leq 0.05$ )

\begin{tabular}{lccc}
\hline & CCD & IM0 & p value \\
\cline { 2 - 3 } & Mean (SD) & Mean (SD) & \\
\hline Bite force & $3.27(0.90)$ & $7.44(5.20)$ & 0.01 \\
MPX50 & $5.54(1.22)$ & $4.03(1.45)$ & 0.01 \\
MPB & $7.42(3.87)$ & $3.83(2.65)$ & 0.01 \\
ME 5.6 & $55.45(29.12)$ & $25.92(30.57)$ & 0.02 \\
ME 4.0 & $16.42(10.41)$ & $15.34(5.67)$ & 0.75 \\
ME 2.8 & $8.05(12.05)$ & $20.26(11.50)$ & 0.01 \\
\hline
\end{tabular}

CCD: conventional complete denture users; IMO: implant mandibular overdenture users. that lower MPX50 values, i.e., improved test food reduction capacity, are associated with higher BF values. When the $M P$ variables were included in a multiple regression model, only the MPX50 outcome was significant in the final model $\left(F=5.05 ; p \leq 0.01 ; r^{2}: 0.33 ; p \leq 0.01\right)$, proving an interrelation between test food reduction (MPX50) and BF for IMO users.

\section{Discussion}

Many studies $(5,10,15,21,23)$ demonstrated that the masticatory performance of IMO users increases, likely because the implants improve retention and stability of the mandibular prostheses. This ensures that the masticatory muscles are used exclusively for chewing and homogenizing the particles, because they are no longer needed to maintain the prostheses in a resting position. After transition to IMO, improvements of around 20\% to $47 \%$ are reported in outcomes such as MPB and in the ME5.6 sieve (23). So far, few studies assessed whether BF correlates with the masticatory performance of IMO users $(8,15)$, and the majority analyzes only differences in the mean values of BF between CCD and IMO users $(14,21,24)$.

Table 2. Intragroup differences in bite force (BF) between dominant side and non-dominant side (t-test; $\mathrm{p} \leq 0.05$ )

\begin{tabular}{lcccc}
\hline & \multicolumn{2}{c}{ BF CCD } & \multicolumn{2}{c}{ BF IMO } \\
\cline { 2 - 5 } Side & Mean & P value & Mean & P value \\
\hline Dominant & 3.75 & 0.04 & 8.00 & 0.38 \\
Non-dominant & 2.79 & & 6.40 & \\
\hline
\end{tabular}

Table 3. Correlations between bite force and masticatory performance outcomes and sample characteristics (Pearson's correlation coefficients)

\begin{tabular}{|c|c|c|c|c|c|c|c|c|c|c|c|c|}
\hline \multirow{3}{*}{ Variables } & \multicolumn{6}{|c|}{ CCD } & \multicolumn{6}{|c|}{ IMO } \\
\hline & $\mathrm{BF}$ & MPX50 & MPB & ME 5.6 & ME 4.0 & ME 2.8 & $\mathrm{BF}$ & MPX50 & MPB & ME 5.6 & ME 4.0 & ME 2.8 \\
\hline & $\begin{array}{c}\text { Coef. } \\
\text { (pvalue) }\end{array}$ & $\begin{array}{l}\text { Coef. } \\
\text { (pvalue) }\end{array}$ & $\begin{array}{l}\text { Coef. } \\
\text { (pvalue) }\end{array}$ & $\begin{array}{c}\text { Coef. } \\
\text { (pvalue) }\end{array}$ & $\begin{array}{l}\text { Coef. } \\
\text { (pvalue) }\end{array}$ & $\begin{array}{c}\text { Coef. } \\
\text { (pvalue) }\end{array}$ & $\begin{array}{c}\text { Coef. } \\
\text { (pvalue) }\end{array}$ & $\begin{array}{l}\text { Coef. } \\
\text { (pvalue) }\end{array}$ & $\begin{array}{c}\text { Coef. } \\
\text { (pvalue) }\end{array}$ & $\begin{array}{c}\text { Coef. } \\
\text { (pvalue) }\end{array}$ & $\begin{array}{l}\text { Coef. } \\
\text { (pvalue) }\end{array}$ & $\begin{array}{l}\text { Coef. } \\
\text { (pvalue) }\end{array}$ \\
\hline Bite force & - & $\begin{array}{l}-0.29 \\
(0.35)\end{array}$ & $\begin{array}{c}0.03 \\
(0.90)\end{array}$ & $\begin{array}{l}-0.26 \\
(0.40)\end{array}$ & $\begin{array}{l}-0.08 \\
(0.78)\end{array}$ & $\begin{array}{c}0.18 \\
(0.57)\end{array}$ & - & $\begin{array}{l}-0.57 \\
(0.05)^{*}\end{array}$ & $\begin{array}{l}-0.36 \\
(0.24)\end{array}$ & $\begin{array}{l}-0.45 \\
(0.13)\end{array}$ & $\begin{array}{l}-0.28 \\
(0.37)\end{array}$ & $\begin{array}{c}0.38 \\
(0.22)\end{array}$ \\
\hline Gender & $\begin{array}{c}0.11 \\
(0.71)\end{array}$ & $\begin{array}{c}0.05 \\
(0.87)\end{array}$ & $\begin{array}{c}0.30 \\
(0.33)\end{array}$ & $\begin{array}{c}0.02 \\
(0.95)\end{array}$ & $\begin{array}{l}-0.14 \\
(0.96)\end{array}$ & $\begin{array}{l}-0.21 \\
(0.50)\end{array}$ & $\begin{array}{c}0.46 \\
(0.12)\end{array}$ & $\begin{array}{l}-0.33 \\
(0.28)\end{array}$ & $\begin{array}{l}-0.39 \\
(0.20)\end{array}$ & $\begin{array}{l}-0.39 \\
(0.21)\end{array}$ & $\begin{array}{l}-0.35 \\
(0.25)\end{array}$ & $\begin{array}{c}0.22 \\
(0.48)\end{array}$ \\
\hline Age & $\begin{array}{c}0.34 \\
(0.27)\end{array}$ & $\begin{array}{l}-0.21 \\
(0.51)\end{array}$ & $\begin{array}{l}-0.23 \\
(0.46)\end{array}$ & $\begin{array}{l}-0.27 \\
(0.38)\end{array}$ & $\begin{array}{c}0.03 \\
(0.90)\end{array}$ & $\begin{array}{l}-0.58 \\
(0.85)\end{array}$ & $\begin{array}{c}0.23 \\
(0.46)\end{array}$ & $\begin{array}{l}-0.22 \\
(0.49)\end{array}$ & $\begin{array}{l}-0.14 \\
(0.64)\end{array}$ & $\begin{array}{l}-0.34 \\
(0.27)\end{array}$ & $\begin{array}{l}-0.46 \\
(0.12)\end{array}$ & $\begin{array}{l}0.16 \\
(0.60)\end{array}$ \\
\hline $\begin{array}{l}\text { Time since } \\
\text { maxillary } \\
\text { edentulism }\end{array}$ & $\begin{array}{l}-0.18 \\
(0.57)\end{array}$ & $\begin{array}{l}-0.10 \\
(0.74)\end{array}$ & $\begin{array}{l}-0.22 \\
(0.48)\end{array}$ & $\begin{array}{l}-0.16 \\
(0.60)\end{array}$ & $\begin{array}{l}-0.40 \\
(0.19)\end{array}$ & $\begin{array}{l}-0.20 \\
(0.51)\end{array}$ & $\begin{array}{l}-0.32 \\
(0.30)\end{array}$ & $\begin{array}{c}0.16 \\
(0.61)\end{array}$ & $\begin{array}{c}0.14 \\
(0.64)\end{array}$ & $\begin{array}{c}0.22 \\
(0.47)\end{array}$ & $\begin{array}{l}-0.70 \\
(0.82)\end{array}$ & $\begin{array}{l}-0.32 \\
(0.30)\end{array}$ \\
\hline $\begin{array}{l}\text { Time since } \\
\text { mandibular } \\
\text { edentulism }\end{array}$ & $\begin{array}{l}-0.21 \\
(0.51)\end{array}$ & $\begin{array}{c}0.04 \\
(0.89)\end{array}$ & $\begin{array}{l}-0.73 \\
(0.82)\end{array}$ & $\begin{array}{l}-0.02 \\
(0.94)\end{array}$ & $\begin{array}{l}-0.49 \\
(0.10)\end{array}$ & $\begin{array}{l}-0.32 \\
(0.30)\end{array}$ & $\begin{array}{l}-0.17 \\
(0.58)\end{array}$ & $\begin{array}{c}0.09 \\
(0.77)\end{array}$ & $\begin{array}{l}-0.55 \\
(0.86)\end{array}$ & $\begin{array}{l}-0.06 \\
(0.84)\end{array}$ & $\begin{array}{l}-0.11 \\
(0.71)\end{array}$ & $\begin{array}{l}-0.02 \\
(0.94)\end{array}$ \\
\hline $\begin{array}{l}\text { Mandibular } \\
\text { bone atrophy }\end{array}$ & $\begin{array}{c}0.02 \\
(0.95)\end{array}$ & $\begin{array}{l}-0.34 \\
(0.27)\end{array}$ & $\begin{array}{l}-0.20 \\
(0.53)\end{array}$ & $\begin{array}{l}-0.36 \\
(0.24)\end{array}$ & $\begin{array}{c}0.16 \\
(0.61)\end{array}$ & $\begin{array}{c}0.22 \\
(0.47)\end{array}$ & $\begin{array}{c}0.28 \\
(0.37)\end{array}$ & $\begin{array}{l}-0.38 \\
(0.22)\end{array}$ & $\begin{array}{c}0.05 \\
(0.86)\end{array}$ & $\begin{array}{c}0.00 \\
(0.99)\end{array}$ & $\begin{array}{l}-0.20 \\
(0.50)\end{array}$ & $\begin{array}{l}-0.20 \\
(0.53)\end{array}$ \\
\hline
\end{tabular}

CCD: conventional complete denture users; IMO: implant mandibular overdenture users; *Significant correlation. 
In the present clinical study, IMO users obtained superior BF and MP values than CCD users and the increased retention of the prostheses provided by two implants was able to equalize the difference in BF between dominant side and non-dominant side. Our robust statistical analysis indicates that BF was only correlated with masticatory performance via the MPX50 outcome of IMO users.

Our results are consistent with those from previous studies analyzing BF in IMO users, which show that these individuals can present BF up to 2 times higher (14) and after 1 year up to $123 \%$ higher (9), when compared to CCD users. The literature shows that CCD wearers use the perioral and masticatory muscles to compensate for the lack of retention and stability of their prostheses, especially the lower prosthesis, and this can result in a decreased $\mathrm{BF}$, as observed in this clinical study. However, Schimmel et al. (21) found no significant differences in BF between the CCD and IMO groups, and this was attributed to the younger mean age of $C C D$ group. It is well-known that age has a direct influence on $\mathrm{BF}$, as increasing age interferes with muscular strength and masticatory muscles of older individuals tend to atrophy, especially when using CCD $\vec{s}(8,21)$. Studies included in a recent review indeed revealed a correlation between age and BF, but the reported effect of age on BF was relatively small. The reported correlation coefficients indicate that age accounts for less than 10\% of the BF variation (8).

The present study found no correlations between BF and the degree of mandibular bone atrophy, masticatory parameters, and sociodemographic variables, such as gender, age, maxillary and mandibular time since edentulism, except for a negative correlation with the MPX50 of IMO users showing that greater $\mathrm{BF}$ improves food comminution. This is consistent with previous studies $(5,25)$ that also found a correlation between $\mathrm{BF}$ and particle comminution. The increased retention and stability generated by the implantretained overdentures resulted in a greater $\mathrm{BF}$ in this group. The correlation with particle comminution can be attributed to this increased stability, as artificial teeth and cusps retained in stable positions are able to crush food more efficiently. Van der Bilt et al. (12) found a significant correlation between the average particle size and the BF immediately after implant installation and this correlation was retained after 10 years of function. Still, BF accounted for almost $60 \%$ of the variation in masticatory performance in this study. In contrast to the present study, previous studies $(12,25)$ found that gender was also related to BF. The absence of a significant gender effect in our study can be attributed to the small number of male participants, in addition to the small absolute effect of gender on BF.

In addition, our results indicate a significant (25.6\%) difference in BF between the dominant- and non-dominant side of CCD wearers. Even more pronounced differences were recently reported by Shala et al. (22), who found a BF in CCD users that was $80 \%$ lower in the non-dominant side. These authors attributed this difference to the individual preference for unilateral chewing, which contributes to muscle tonicity improvements and consequently results in greater BF (22). In our study, the BF of IMO users was similar on both sides, indicating that IMO use equalizes the BF on both sides. This finding is in agreement with the results of Melo et al. (26), but contrasts with the results of Rismanchian et al. (11), who found that the BF in the dominant side was $21.7 \%$ higher. Nonetheless, the superior retention and stability provided by IMO likely allow for a more balanced mastication in most cases.

The main limitations of this study include the lack of electromyographic data and quantification of saliva production during function, which are important masticatory variables and could contribute to the understanding of the relationship between bite force and masticatory performance. In addition, future studies are needed to analyze the relationship between these variables after a longer adaption period with both rehabilitation types, to assess whether the adaptation time can influence the results. Some studies have shown that the BF and MP of CCD users can improve gradually over time $(21,27-$ 29). Clinical studies should also strive for equal gender distributions in the sample population and larger sample sizes to enable assessment of subtler (gender-related) effects.

In conclusion, IMO users achieve higher BF and better masticatory performance than CCD wearers, alongside a lower difference in BF between dominant and nondominant sides. Masticatory performance in the IMO group correlates with higher BF through improved particle crushing capabilities.

\section{Resumo}

Este estudo observacional transversal com 24 participantes teve como objetivo avaliar as diferenças na força de mordida (FM) e na PM (performance mastigatória) entre usuários de prótese total convencional (PTC) e de overdenture mandibular (OM) e a correlação entre essas variáveis. 0 teste de FM foi realizado bilateralmente com um dispositivo de força oclusal. Durante o teste de PM, os pacientes foram solicitados a mastigar uma porção padronizada de Optocal por 40 ciclos mastigatórios. 0 teste de Shapiro Wilk foi empregado para verificar a normalidade dos dados, o teste T de Student para identificar diferenças entre os grupos e os coeficientes de correlação de Pearson para investigar inter-relações entre variáveis. Uma regressão linear múltipla foi realizada pelo método stepwise. Valores de $p \leq 0,05$ foram considerados estatisticamente significantes. Diferentemente dos usuários de OM, os usuários de PTC apresentaram uma diferença significativa (34\%) na FM entre o lado dominante e o não dominante $(p=0,04)$. Os usuários de $0 M$ apresentaram $F M$ significativamente maior $(p=0,01)$ sem apresentar um lado dominante $(p=0,38)$ e obtiveram PM significativamente melhor nos seguintes parâmetros: os valores de PMX50 diminuiram 27,25\% ( $p=0,01)$, PMB diminuiu em $48,38 \%(p=0,01)$, e EM 5.6 diminuiu 53,25\% ( $p=0,02)$, enquanto EM2.8 aumentou 151,57\% 
$(p=0,01)$. A FM e PMX50 no grupo de usuários da IMO foram negativamente correlacionados $(-0,57 ; p=0,05)$; esse coeficiente de correlação foi o único parâmetro incluido no modelo de regressão multivariada. Os usuários da $\mathrm{OM}$ possuem maior FM e melhor performance mastigatória do que os usuários de PTC, observados principalmente na redução do tamanho das partículas mastigadas. A PM está correlacionada com um maior FM nos usuários da OM através de uma melhor trituração de partículas.

\section{References}

1. Marcello-Machado RM, Faot F, Schuster AJ, Bielemann AM, Nascimento GG, Del Bel Cury AA. How fast can treatment with overdentures improve the masticatory function and $\mathrm{OHRQ}$ oL of atrophic edentulous patients? A 1-year longitudinal clinical study. Clin Oral Implants Res. 2018;29:215-226.

2. Possebon AP da R, Marcello-Machado RM, Bielemann AM, Schuster $A J$, Pinto $L$ de $R$, Faot $F$. Masticatory function of conventional complete denture wearers changing to 2-implant retained mandibular overdentures: clinical factor influences after 1 year of function. J Prosthodont Res 2018;62:479-484.

3. Feine JS, Carlsson GE, Awad MA, Chehade A, Duncan WJ, Gizani S, et al. The McGill consensus statement on overdentures. Mandibular twoimplant overdentures as first choice standard of care for edentulous patients. Gerodontology 2002;19:3-4.

4. Thomason JM, Kelly SAM, Bendkowski A, Ellis JS. Two implant retained overdentures - A review of the literature supporting the McGill and York consensus statements. J Dent 2012:40:22-34.

5. Fontijn-Tekamp FA, Slagter AP, Van Der Bilt A, Van 'T Hof MA, Witter DJ, Kalk W, et al. Biting and chewing in overdentures, full dentures, and natural dentitions. J Dent Res 2000;79:1519-124.

6. Sharma A, Nagrath R, Lahori M. A comparative evaluation of chewing efficiency, masticatory bite force, and patient satisfaction between conventional denture and implant-supported mandibular overdenture: An in vivo study. J Indian Prosthodont Soc 2017:17:361.

7. Ikebe K, Nokubi T, Morii K, Kashiwagi J, Furuya M. Association of bite force with ageing and occlusal support in older adults. J Dent 2005;33:131-137.

8. Van Der BILT A. Assessment of mastication with implications for oral rehabilitation: a review. J Oral Rehabil 2011;38:754-780.

9. Enkling N, Saftig M, Worni A, Mericske-Stern R, Schimmel M. Chewing efficiency, bite force and oral health-related quality of life with narrow diameter implants - a prospective clinical study: results after one year. Clin Oral Implants Res 2017;28:476-482.

10. Bakke $M$, Holm B, Gotfredsen K. Masticatory function and patient satisfaction with implant-supported mandibular overdentures: a prospective 5-year study. Int J Prosthodont 2002;15:575-581.

11. Rismanchian M, Bajoghli F, Mostajeran Z, Fazel A, Eshkevari P Sadr. Effect of implants on maximum bite force in edentulous patients. J Oral Implantol 2009;35:196-200.

12. Van Der Bilt A, Burgers M, Van Kampen FMC, Cune MS. Mandibular implant-supported overdentures and oral function. Clin Oral Implants Res 2010;21:1209-13.

13. Sônego MV, Goiato MC, dos Santos DM. Electromyography evaluation of masseter and temporalis, bite force, and quality of life in elderly patients during the adaptation of mandibular implant-supported overdentures. Clin Oral Implants Res 2017;28:e169-e174.

14. Fontijn-Tekampl E, Slagter AP, van't Hof MA, Geertman ME, Kalk W. Bite Forces with Mandibular Implant-retained overdentures. J Dent Res 1998;77:1832-1839.
15. Boven GC, Raghoebar GM, Vissink A, Meijer HJA. Improving masticatory performance, bite force, nutritional state and patient's satisfaction with implant overdentures: A systematic review of the literature. J Oral Rehabil 2015;42:220-233.

16. Müller $F_{1}$ Hernandez $M$, Grütter $L$, Aracil-Kessler $L$, Weingart $D$, Schimmel M. Masseter muscle thickness, chewing efficiency and bite force in edentulous patients with fixed and removable implantsupported prostheses: A cross-sectional multicenter study. Clin Oral Implants Res 2012;23:144-150.

17. Raustia AM, Salonen MAM, Pyhtinen J. Evaluation of masticatory muscles of edentulous patients by computed tomography and electromyography. J Oral Rehabil 1996;23:11-16.

18. Caloss R, Al-Arab M, Finn RA, Lonergan O, Throckmorton GS. Does long-term use of unstable dentures weaken jaw muscles? J Oral Rehabil 2010;37:256-261.

19. Heckmann SM, Heußinger $S$, Linke JJ, Graef F, Pröschel P. Improvement and long-term stability of neuromuscular adaptation in implantsupported overdentures. Clin Oral Implants Res 2009;20:1200-1205.

20. Van Kampen FMC, Van Der Bilt A, Cune MS, Fontijn-Tekamp FA, Bosman F. Masticatory function with implant-supported overdentures. J Dent Res 2004;83:708-711.

21. Schimmel M, Memedi K, Parga T, Katsoulis J, Müller F. Masticatory Performance and Maximum Bite and Lip Force Depend on the Type of Prosthesis. Int J Prosthodont 2017;30:565-572.

22. Shala K, Tmava-Dragusha A, Dula L, Pustina-Krasniqi T, Bicaj T, Ahmedi $E_{1}$ et al. Evaluation of maximum bite force in patients with complete dentures. Open Access Maced J Med Sci 2018;6:559-563.

23. Marcello-Machado RM, Bielemann AM, Nascimento GG, Pinto $L$ de $R$, Del Bel Cury AA, Faot $F$. Masticatory function parameters in patients with varying degree of mandibular bone resorption. J Prosthodont Res 2017;61:315-323.

24. Geckili O, Bilhan H, Mumcu E, Dayan C, Yabul A, Tuncer N. Comparison of patient satisfaction, quality of life, and bite force between elderly edentulous patients wearing mandibular two implant-supported overdentures and conventional complete dentures after 4 years. Spec Care Dent 2012;32:136-141.

25. Hatch JP, Shinkai RS, Sakai S, Rugh JD, Paunovich ED. Determinants of masticatory performance in dentate adults. Arch Oral Biol 2001:46:641-648.

26. Melo ACM, Ledra IM, Vieira RA, Coró ER, Sartori IAM. Maximum Bite Force of Edentulous Patients before and after Dental Implant Rehabilitation: Long-Term Follow-Up and Facial Type Influence. J Prosthodont 2018:27:523-527

27. Müller F, Heath MR, Ott R Maximum Bite Force After the Replacement of Complete Dentures. Gerodontology 2001;18:58-62.

28. Leles $C R$, Oliveira TMC, de Araújo SC, Nogueira TE, Schimmel M. J Oral Rehabil. Individual factors associated with masticatory performance of complete denture wearers: A cross-sectional study. J Oral Rehabil. 2019;46:903-911.

29. Nogueira $T E$, Schimmel $M$, Leles $C R$. Changes in masticatory performance of edentulous patients treated with single-implant mandibular overdentures and conventional complete dentures. J Oral Rehabil 2019:46:268-273. 